\title{
THE ISSUE OF ARMENIAN GENOCIDE RECOGNITION AND ARMENIAN-TURKISH RE- LATIONS IN THE FOREIGN POLICY OF THE RA (1991-1996)
}

\begin{abstract}
In 1991 Turkey recognized the independence of Armenia but did not establish diplomatic relations with the latter, the only reason of which was not to face its own history and refuse the fact of the Genocide. Although Ter-Petrosyan's regime did not include the fact of the Genocide recognition on the agenda of foreign policy of the RA, however, it did not bring any positive changes in relations with Turkey. On the contrary, the Turks did not miss the opportunity to put forward their preconditions of illegal nature to normalize relations.
\end{abstract}

Keywords: Armenia, Turkey, international recognition, demands, Armenian-Turkish relations, symposium.

Turkey recognized the independence of Armenia on December 16, 1991. It seemed, that out of its own interests, Turkey would establish goodneighborly relations with especially Armenia among its neighbors, we think because of the reasons as follows:

1. Turkey holds territorial and other arguable issues with almost all its neighbors in the region, so establishing neighborly relations with Armenia it would make the latter opt out of the affiliation of countries possessing anti-Turkish moods.

2. Establishing diplomatic relations with Armenia Turkey would have a chance to repair its damaged reputation in front of the international community at least for a while.

3. Turkey would have a chance to enter The Southern Caucasus with no obstacle, keeping Russia's military-political presence in the region to minimum. (Taregirq 2015: 64).

In spite of all, Turkey not only refused to establish diplomatic relations, but also put forward a number of preconditions to normalize bilateral relations. The realization of the preconditions for Yerevan would mean a renunciation of the Artsakh
Liberation War conquests, as well as a new genocide of the historical memory of the Armenian nation $^{1}$.

Official Ankara has repeatedly declared the preconditions for starting a dialogue with Yerevan. On the contrary, Yerevan insists on the significance of building relations with no preconditions. Ankara's similar policy is a result of clear geopolitical calculations, for the Armenian-Turkish relations are also just one tip of the Caucasian geopolitical iceberg. Let's bear in mind, it is in this region that the interest of the main powers of the international relations - The USA, Russia, The UN and others, get crossed. In such conditions, the issue of the Armenian-Turkish relations grabs a considerable part of the international community's attention.

Trying to start a dialogue with its Western neighbor, Armenia excluded the issue of Armenian Genocide recognition from its foreign political priorities in the first phase of the independence, though the importance of the international recognition of the "Great Catastrophe" was fixed in the

\footnotetext{
${ }^{1}$ Armenia and Turkey had a very short experience of intergovernmental relations during 1918-1920 (about the issue see Xatisyan 1930, Vracyan 1928).
} 
Declaration of Independence passed on August 23, 1990. Official Yerevan came up with reconciliation statements supporting the magnitude of establishing good-neighborly relations with neighboring states $^{2}$.

Powers that be, the leaders of the Armenian National Movement, considered it groundless and subversive for Armenia to exist in support of only one state, while being surrounded by hostileoriented countries.

Already in November, 1990, The ANM leader L. Ter-Petrosyan during the second party convention announced, "Let's look for and create more trustful guarantees for the existence of our nation. The normalization of the relations between Armenia and Turkey is only one of the circles of these guarantees." 3

Turgut Öza, Turkey's president, reacted to $\mathrm{L}$. Ter-Petrosyan's announcement positively. Thus, on January 7, 1991 (day $32^{\text {nd }}$ ), answering the question of a famous Turkish publicist Mehmet Ali Birand on a Turkish Television, he underlined Turkey's plans to establish economic relations with Armenia ${ }^{4}$. It goes without saying, this announcement could have a positive influence on the Armenian-Turkish relations.

Literally, Turks couldn't but worry about the fact that the significance of pursuing the Armenian Genocide International Recognition was included in the Armenian Declaration of Independence. For some period, the Turkish side managed to reach the exclusion of the Genocide issue from official Yerevan's foreign policy agenda. It's noteworthy, that Ankara specified its stance on Armenia only in April 1991, when Volkan Vural, ambassador of Turkey to the USSR, took a 3-day official visit to Armenia (Arshakyan 2009: 51). Receiving the Turkish diplomat, L. Ter-Petrosyan particularly stated. “Ar-

\footnotetext{
2 See at Hayastani Hanrapetut'yun o'rat'ert' (The Republic of Armenia daily) 28.11.1990.

3 Hayastani Hanrapetut'yun o'rat'ert' (The Republic of Armenia daily) 28.11.1990.
}

${ }^{4}$ Azq o'rat'ert' (Nation daily) 17.04.1991. menia experiences changes, and we should be neighbors with new thinking in this new world. We are ready for any mutually beneficial cooperation. Armenia has no territorial demands from Turkey" ${ }^{5}$.

Hence, The Ter-Petrosyan's regime anchored the framework of Armenian-Turkish relations normalization at a more moderate ground. In fact, the newly independent state would not raise the issue of Armenian Genocide International Recognition in the context of bilateral relations, thus confiding it to the Diaspora ${ }^{6}$.

The Turkish diplomat held his own view on the development of the Armenian-Turkish relations. If for Armenia the activation issues of economic relations were of priority, the Turkish side highlighted the normalization of Karabakh Issue and recognition of the existing Armenian-Turkish border (Safrastyan 2003: 39).

Ankara tried to oblige Armenia to deter official Yerevan from adopting a policy of the international recognition of Genocide. They thought in Ankara that in case of realizing the Turkish scenario, Armenia would convince the Diaspora of following them ${ }^{7}$.

The Embassy of Turkey to Moscow, headed by Ambassador V. Vural soon went too far coming up with a note of protest, in particular stating. "No state unit neighboring Armenia can and should give a piece of land to the RA... an appeal and moreover the distortion of historical facts is impermissible ${ }^{\prime 8}$.

Trying to alleviate the unrest among Turkish political regions on the $1^{\text {st }}$ point of August 23 Declaration, 1992, L. Ter-Petrosyan, already as an RA president, answered the Turk journalist's question during the interview with "Jumhuriyat" newspaper.

\footnotetext{
${ }^{5}$ Azg o'rat'ert' (Nation daily) 30.05.2002.

${ }^{6}$ HH GAA Hayoc ceghaspanut'yan t'angaran-instituti fond (The Armenian Genocide Museum-institute found), Bajhin 32, t'p 26, p' 5, p. 4.

${ }^{7}$ HH GAA Hayoc ceghaspanut'yan t'angaran-instituti fond (The Armenian Genocide Museum-institute found), Bajhin 32, t'p 26, p' 5, p. 4.

8 Nezavisimaya gazeta (Independent Newspaper), 14.05.1991.
} 
The question was as follows: "The expression "Western Armenia" is found in the Armenian Declaration of Independence passed on August 23, 1990. What do you think, does it introduce the demanding into the agenda itself?" The answer was. "The Declaration had been passed before the USSR collapse, and Armenia was neither a member of the CSCE nor of the UN yet. We are currently clarifying the frameworks of the Independence. However, per the CSCE principles, which we regard, that expression itself is excluded from the agenda. Let me announce clearly, that we are faithful to the principles of border security and don't put an eye on a territory of other countries. Armenia has no demand of land from any neighbor, and it concerns both Turkey, Georgia and Azerbaijan (Xurshudyan 1995: 7980). As they say, comments on this point are unnecessary."

In fact, L. Ter-Petrosyan renounced the constituent areas of the Armenian historical homeland in favor of Turkey, Azerbaijan and Georgia and without considering the opinion of the Armenian people. A fact the latter couldn't reconcile with.

The ANM Authorities were sure that in case of leaving the Issue of the Armenian Genocide Recognition out of the RA foreign policy, the independent Armenia would have more threats comparing with the Soviet Armenia vis-a-vis transferring the issue to the state political platform. There was no Soviet Union as a security system, no new security systems, nor was the Armenian army formed, there was also the Karabakh Issue and at last, there were superpowers' conflicting interests together with geopolitical and regional rearrangements taking place." $^{9}$

We think that this is not a well-supported thesis, because, particularly without touching upon the issue of the recognition of the Armenian Genocide, Armenia was not strengthening its own security. Besides, during the Nagorno-Karabakh conflict Turkey fully displayed all the possible forms of open

\footnotetext{
${ }^{9}$ Ar'avot o'rat'ert' (Morning daily) 21.10.2000.
}

hostility, but for armed attack on Armenia (Chakryan 2001: 17-19), Ayvazyan 1998: 21-37).

In the context of the mentioned facts, referring to the issue of the Turkish - Armenian relations, turkologist $\mathrm{H}$. Chakryan quite correctly states that among us the importance of establishing relations with Turkey was overestimated, Ankara in turn underestimated the possibility of the potential Armenian-Russian alliance, that is why Turkey recognized Armenia's independence, but did not establish diplomatic relations with it ${ }^{10}$.

In July 1992, Ter-Petrosyan - Demirel meeting took place, which had been preceded by meeting between the Turkish Prime Minister and his Armenian counterpart, $\mathrm{H}$. Bagratyan.

Already in August 1992, the Turkish diplomatic delegation headed by the Deputy Minister of Foreign Affairs, B. Unan, paid official visit to Armenia. According to the foreign policy advisor to the first President of the RA, Zh. Liparityan, during the negotiations with the Turkish MFA the issue of the international recognition of the Armneian Genocide was not discussed (Ananyan 2006: 3). However, the issue of the Armenian Genocide, according to the advisor to the first President of the RA, Zh. Liparityan, "was informally raised on different occasions, as well as other issues of common interest"11 in the context of the Armenian-Turkish dialogue.

On March 12, 1993 in a hotel in Paris, the head of the Turkish "Grey Wolves", Türkeş, had a secret meeting with the President of the Republic of Armenia, Levon Ter-Petrosyan. "Milliyet", once being referred to as Ter-Petrosyan's retainer, provides the Armenian Samson Eozararat, who was born in Turkey, with media clarifications, as well as clarifications on secret meetings ${ }^{12}$. It is noteworthy that the meeting with Türkeş was initiated by the

${ }^{10}$ HH GAA Hayoc ceghaspanut'yan t'angaran-instituti fond (The Armenian Genocide Museum-institute found), Bajhin 32, t'p 26, p' 3, p. 1.

11 HH GAA Hayoc ceghaspanut'yan t'angaran-instituti fond (The Armenian Genocide Museum-institute found), Bajhin 32, t'p 26, p' 5, p. 3.

12 Yerkir o'rat'ert' (Country daily) 29.04.2005. 
Armenian side. For the settlement of the ArmenianTurkish relations and Artsakh conflict Türkeş put forth six preconditions:

1. Cease-fire is established between Armenia and Azerbaijan,

2. Armenian soldiers leave the occupied territories,

3. Both sides recognize each other's borders,

4. The practice of interfering in one another's internal affairs is excluded,

5. The Lachin corridor is announced open and observers are deployed there,

6. The Artsakh conflict is settled after the ceasefire, within the framework of the Minsk Group.

According to Eozararat's testimony, sometime later after the meeting the possibility of building a monument to the victims of 1915 on the ArmenianTurkish border was discussed. There would be a note on both sides of the monument in Armenian and Turkish: "We grieve for the pain we caused". The newspaper does not explain what kind of pain the Armenians caused the Turks, what kind of crime they committed that would be equivalent to the Armenian Genocide of 1915-1923. The Armenians and Turks are considered on the same level: both sides share the guilt. In fact, Ter-Petrosyan and Türkeş's meeting ended in vain.

It is not difficult to guess from the abovementioned that the Turkish side has never refused to consider the Armenian Genocide as a precondition for establishing bilateral relations. Even in October 1993 at the Turkish Embassy in Moscow, after the meeting with the President of Armenia, Ambassador Kamil announced that in order to improve Armenian-Turkish relations Armenia should refuse to touch upon the events of 1915 (Kurtov, Khalmukhamedov 1998: 455). According to the testimony of the former Minister of Foreign Affairs, A. Arzumanian, the Turkish preconditions for establishing official relations with the RA were also: "Not to mention the Armenian Genocide, to abandon claims officially, to stop the anti-Turkish activities of the Armenian Diaspora"13.

In 1996-1997 the Armenian side was trying to move the dialogue to an economic platform hoping that economic interest would promote to start political dialogue without any preconditions. In this way the First Deputy Minister of Foreign Affairs, V. Oskanian, thought that if Turkish businessmen got profits, they could influence the Turkish authorities and the latter would abandon the preconditions already put forth.

However, Turkey still refuses to establish diplomatic relations with Armenia and continues to insist on its previous preconditions (Manukyan 2005: 34).

Today, we are happy to emphasize that in the international arena Armenia does not weaken its position concerning the question under discussion.

As evidence for the above mentioned we quote some part of RA President, Serzh Sargsian's speech at the $100^{\text {th }}$ anniversary of the Armenian Genocide, which particularly says, "Expressing the united will of the Armenian people, based on the Declaration of Independence of Armenia of $23 \mathrm{Au}$ gust, 1990 and the Constitution of the Republic of Armenia (Minasyan 2003: 246), recalling the United Nations Universal Declaration of Human Rights of 10 December, 1948 (Harut'yunyan 2005: 14), reiterates the commitment of Armenia and the Armenian people to continue the international struggle for the prevention of genocides, the restoration of the rights of people subjected to genocide and the establishment of historical justice. Confirms that the Armenian people will always remain standing by the side of those who suffered from crimes against humanity. The unyielding international struggle against crimes of genocide will remain an integral part of our foreign policy" ${ }^{14}$.

13 Haykakan jhamanak (Armenian Times daily) 18.07. 2002.

$14 \mathrm{htpt//president.am/hy/press-release/item/2015/04}$ /24/President-Serzh-Sargsyan-Genocide-April-24/ 


\section{REFERENCES}

Ayvazyan, A.M. (1998). Gharabaghyan hakamartut'yan kargavorumy' \& Hayastani razmavarakan anvtangut'yuny' (Karabakh Conflict Settlement and Armenian Strategic Security). Yerevan: Hayinfo gorc'akalut'yun.

Ananyan, A.L. (2006). Hayoc ceghaspanut'yan himnaxndiry' hay-t'urqakan haraberut'yunnerum (1991-2004t't'.) (The Issue of the Armenian Genocide in the ArmenianTurkish Relations (1991-2004)). Yerevan: HH GAA patmut'yan institut.

Arshakyan, G. (2009). T'urqiayi qaghaqakanut'yuny' Haravayin Kovkasum 1991-2001t't'. (The Policy of Turkey in South Caucasus in 1991-2001). Yerevan: HH GAA Gitut'yun hratarakchut'yun.

Xatisyan, A.H. (1930). Hayastani Hanrapetut'yan c'agumn u zargacumy' (Origin and Development of the Republic of Armenia). Atenq: Nor o'r hratarakchut'yun.

Xurshudyan, L.A. (1995). Haykakan harc (Armenian Issue). Yerevan: Hay krt'akan mshakut'ayin miut'yan hratarakchut'yun.

Minasyan, E'.G. (2003). Social-tntesakan verapoxumnery' Hayastani Hanrapetut'yunum (1990-2003t't'.) (Socioal-Economic Reforms in the Republic of Armenia (19902003)). Yerevan: Yerevani hamalsaranakan hratarakchut'yun.

Safrastyan, R.A. (2003). Hnaravor che 21-rd darum patneshner steghc'el har\&anneri mij\&... (It is Impossible to Create Barriers between Neighbors). Yerevan: Zangak-97.

Vracyan, S.L. (1928). Hayastani Hanrapetut'yun (The Republic of Armenia). Yerevan.

Taregirq (Yearbook) (2005). Yerevan: EPH Patmut'yan fakultet.
Harut'yunyan, A. (2005). "Ceghaspanut'yun" haskacut'yuny'. Hayaspanut'yuny' vorpes ceghaspanut'yan drs\&orum (The Concept "Genocide". Armenocide as a Manifestation of Genocide). Gyumri: Mec' Eghern90, hanrapetakan gitakan nstashrjani nyut'er.

Manukyan, Jh. (2005). Hay-t'urqakan haraberut'yunnery' \& Hayoc ceghaspanut'yan xndirnery' (1991-2002t't' $t^{\prime}$ ) (Armenian-Turkish Relations and Armenian Genocide Issues (1991-2002)). Yerevan: Taregirq 2005.

Chaqryan, H. (2001). T'urqian Hayastani het erkxosut'yun chi cankanum, ayl ceghaspanut'yan banad'\&ery' chezoqacnelu hamar da shaharkum e (Turkey does not Want a Dialogue with Armenia, but Manipulates it to Neutralize the Formulas of Genocide). O'rer 2005, t'iv 1-4.

Kurtov, A.A., Khalmukhamedov, A.M., (1998). Armeniya-Turtsiya: Protivostoyanie ili Sotrudnichistvo? "Armeniya: Problemy nezavisimogo rasvitiya" (Armenia-Turky: Confrontation or Cooperation? "Armenia: the Problems of Independent Development"). Moskva.

Azg o'rat'ert' (Nation daily) 1991-2002:

Ar'avot o'rat'ert' (Morning daily) 2000.

Yerkir o'rat'ert' (Country daily) 2005:

Hayastani Hanrapetut'yun o'rat'ert' (The Republic of Armenia Daily) 1990.

Haykakan jhamanak (Armenian Times daily) 2002:

Nezavisimaya gazeta (Independent Newspaper), 1991.

HH GAA Hayoc ceghaspanut'yan t'angaran-instituti fond (The Armenian Genocide Museuminstitute found of the National Academy of Sciences of Armenia), Bajhin 32, t'p 26. 